
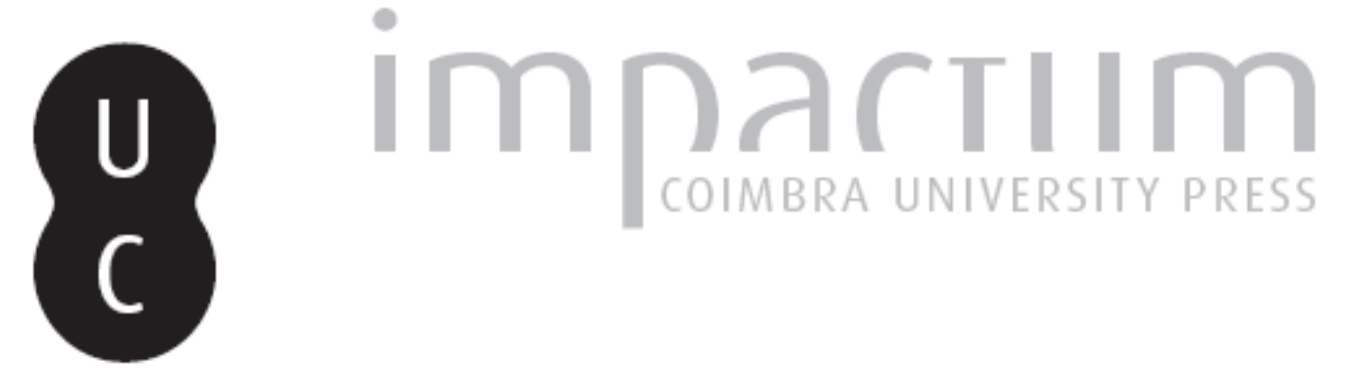

\title{
Scholarship overview on Gnosticism and early Jewish-Christian writings: (re)mantling categories about ancient religious phenomena
}

\author{
Autor(es): $\quad$ Assis, Jean Felipe de \\ Publicado por: Imprensa da Universidade de Coimbra; Annablume \\ URL \\ persistente: \\ URI:http://hdl.handle.net/10316.2/44810 \\ DOI: \\ DOI:https://doi.org/10.14195/1984-249X_25_1 \\ Accessed : $\quad$ 26-Apr-2023 13:12:55
}

A navegação consulta e descarregamento dos títulos inseridos nas Bibliotecas Digitais UC Digitalis, UC Pombalina e UC Impactum, pressupõem a aceitação plena e sem reservas dos Termos e Condições de Uso destas Bibliotecas Digitais, disponíveis em https://digitalis.uc.pt/pt-pt/termos.

Conforme exposto nos referidos Termos e Condições de Uso, o descarregamento de títulos de acesso restrito requer uma licença válida de autorização devendo o utilizador aceder ao(s) documento(s) a partir de um endereço de IP da instituição detentora da supramencionada licença.

Ao utilizador é apenas permitido o descarregamento para uso pessoal, pelo que o emprego do(s) título(s) descarregado(s) para outro fim, designadamente comercial, carece de autorização do respetivo autor ou editor da obra.

Na medida em que todas as obras da UC Digitalis se encontram protegidas pelo Código do Direito de Autor e Direitos Conexos e demais legislação aplicável, toda a cópia, parcial ou total, deste documento, nos casos em que é legalmente admitida, deverá conter ou fazer-se acompanhar por este aviso.

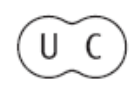




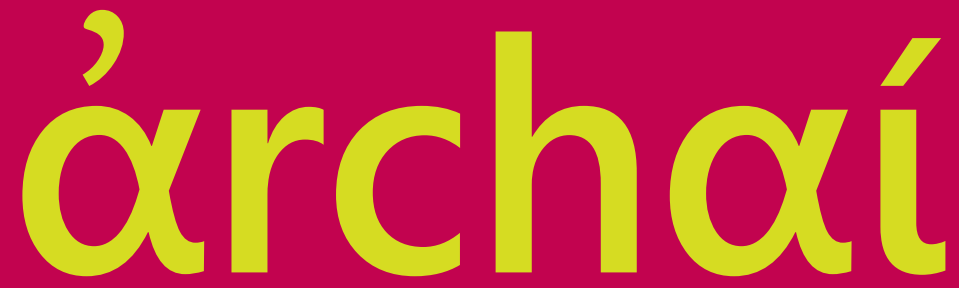

AS ORIGENS DO PENSAMENTO OCIDENTAL

THE ORIGINS OF WESTERN THOUGHT 


\title{
ảrchaí
}

AS ORIGENS DO PENSAMENTO OCIDENTAL

THE ORIGINS OF WESTERN THOUGHT

ARTIGO ORIGINAL I ORIGINAL ARTICLE

\section{Scholarship Overview on Gnosticism and Early Jewish-Christian Writings: (re)mantling Categories about Ancient Religious Phenomena}

\author{
Jean Felipe de Assis ${ }^{\mathrm{i}}$ \\ http://orcid.org/0000-0001-9292-9228 \\ jeanfelipe@hcte.ufrj.br \\ ${ }^{\mathrm{i}}$ Universidade Federal do Rio de Janeiro - Rio de Janeiro - RJ - Brasil \\ ASSIS, J. F. (2019). Scholarship Overview on Gnosticism and Early Jewish- \\ Christian Writings: (re)mantling Categories about Ancient Religious \\ Phenomena. Archai 25, p. 17-39.
}

Abstract: Gnosticism as an organized social movement with a coherent and uniform message is an ambiguous terminology. However, the existence of distinct elements that are simultaneously present in texts established as gnostic and New Testament writings is 
unquestionable. There is a primeval milieu shared among particular communities based on several literary receptions in which diverse ancient religious phenomena, gradually, became consolidated. Critical studies reveal a mandatory revaluation of modern scholarship categories, including essential terms such as Gnosticism and Gnosis; terminological references and religious expressions in the first century do not exclude the presence of shared ideas within the Christian Testament and other Jewish mythic configurations. There are multiple understandings and applications of the term Gnosticism in contemporary scholarship, including those which deliberate evident issues of definition. As a result, a brief scholarship review regarding selected dimensions of Gnostic ideas in the ancient Mediterranean context provides historical and literary grounds for textual analysis in the Jewish-Christian mythmaking and the reception processes of biblical writings in the ancient world. Consequently, by dis-mantling and re-mantling these ancient religious horizons, scholars consider a comprehensive approach of the ancient Hellenistic religious phenomena in which elements from Gnosticism, Apocalypticism, Ancient Magic and Mystery Religions share historical contexts and furnish complex symbolic communications in their specific textual expressions.

Keywords: Gnosticism, Hellenistic Religions, Early Christian Writings, Reception Theory, Jewish-Christian mythmaking.

This is the second of a three-part research project on Early Christianities focusing on Gnosticism and the Pauline traditions. In the first paper, a review on social status of the Pauline ekklesiae furnishes enough theoretical considerations to investigate the history of interpretation of Paul's letters. Understanding these epistles as theological treatises received and reconsidered in later contexts reveals how rhetorical performances based on different traditions interacts with the mythmaking process in diverse early Christian communities. Consequently, theological differences and social stratification are interrelated in the development of early ecclesiological life. In the third investigation, while considering the reception of the Pauline letters, it becomes clear how antagonistic 
interpretations co-exist in religious or cultural expressions throughout multiple receptions, attestations and interpretations of Pauline ideas. As natural developments in a complex system of communication, these several attentions gradually reveal a more consolidated Pauline tradition, since Patristic authors are able to cite entire chapters or books, combining multiple ecclesiological traditions and rejecting those doctrines that they do not believe represent Christian life. Consequently, early multiple interpretations of these materials generate later theological differences, i.e., enthusiastic pneumatological characteristics based on realized eschatology may provide an intellectual framework for later gnostic ideas. Hence, this second paper of this research project stresses the necessity of a revision on Gnostic terms, definitions and history of interpretation in order to establish clear criteria on the diverse interpretations on New Testament writings and also to inquire the roots on which these intellectual conceptualizations took place. Regarding Gnosticism, and the respective derived terms, the possibility of sharing literary elements and intellectual views with different phenomena in the ancient world promote not only the dismantling of modern categories, but also a necessary re-evaluation of scholarship about ancient religious movements. The JewishChristian roots present in various gnostic texts during second and third centuries do not impose the same conceptualization during the first century's intellectual productions; nevertheless, the inexistence of gnostic textual references and religious organizations in the first century do not exclude the presence of shared ideas with the New Testament mythic configuration. A mandatory revaluation of modern scholarship categories, understood as fictitious artifacts in the composition of historical methodologies, allows new approaches that dismantle artificial distinctions among Gnosticism, Apocalypticism, Ancient Magic and other movements while creating spaces for integrating essential common elements present in several ancient religious expressions.

Accepting the literary composition of the Christian biblical writings as a reception of early traditions starting in the late first century demands a social location where ecclesiological debates and 
theological controversies of different traditions share the same milieu. ${ }^{1}$ Consequently, researches about origins that aim to establish a primeval and pure Pauline expression, original gospel narratives, and first sources to specific books or original literary forms with their primordial pragmatic context are not effective. ${ }^{2}$ Therefore, a conceivable first effort to highlight this diversity is an overview of possible gnostic ideas in the Christian canonical texts, which is one famous corollary from History of Religions Studies in the New Testament framework. ${ }^{3}$

Some methodological and practical considerations are in order: first, the multiplicity of religious phenomena and experiences must be seriously taken into consideration; the definitions of Gnosis and Gnosticism are extremely problematic because of the absence of primary textual evidence and now because of the lack of coherent systematizations to understand a variety of phenomena and texts that can be associated with Gnostic ideas; finally, depending on the definition of these terms, Gnostic categories cannot be applied to

\footnotetext{
${ }^{1}$ Taking into account the possibility of approaching the biblical books as textual materials written through constant receptive processes in which literary and sociological formations exist in tandem, mantling and dismantling traditions through textual productions continuously combine theological debates and social conflicts. Therefore, Jewish-Christian biblical writers gradually transfer personal authorship to communitarian writers and, subsequently, these textual materials reach a certain public domain in the first centuries of our common era. Consequently, a milieu between the primitive Jewish-Christian communities and the later third century orthodoxies allows a limitrophe area in which several traditions with blends, fusions and mixtures consolidate the beginning of clear boundaries and delimitations among different social-religious movements (Hauser and Watson, 2003, p. 52-54).

${ }^{2}$ Additionally, pejorative notions that are commonly associated with terms such as syncretism, corruption, interpolation, post-Pauline and so forth are useless categories that masquerade different perspectives in the ancient contexts in order to privilege a theoretical construction with clear contemporary rhetorical attempts.

${ }^{3}$ The influence and benefits of the History of Religions approach for understanding the emergence of Christian traditions in the ancient world are enormous (Pearson, 2001, p. 81-106). However, in this paper, neither will such arguments be summarized nor exegetical analysis will be exposed, since a later general overview about Gnosticism is crucial to our thesis. A famous example for Corinthians and the Pauline letters is the work of Walther Schmithals (1971; 1972; 1965, p. 13-15).
} 
New Testament materials or it underlies their mythic productions. Consequently, by observing these initial issues, it is clear that this approach complicates more than elucidates the already elusive New Testament writings. Conversely, because of this uncomfortable situation, scholars have proposed different approaches to understand the literary productions of early Christianities, including a comprehensive approach of the ancient Hellenistic religious phenomena in which elements from Gnosticism, Apocalypticism, Ancient Magic and Mystery Religions are amalgamated. ${ }^{4}$

The Gospel of John has been the text par excellence from which scholars diverge regarding diverse positions on syncretic characteristics of ancient religious and their influence on early ecclesiological communities. ${ }^{5}$ In the particular case of Gnosticism, Brown asserts that the relationship with a solid gnostic textual evidence can only be possible to second century compositions; although, pre-Christian reconstructions from proto-Gnostic elements

\footnotetext{
4 There are two clear tendencies in this argumentation: first, the uncritical acceptance of theoretical categories in which literary productions, intellectual conceptualizations and social movements furnish ideas for methodological inferences in specific ancient religious historical records; nevertheless, it is possible to compare multiple ancient religious experiences observing common grounds and particularities in different contexts. Consequently, by dismantling specific intellectual categories that aim to frame ancient religious consideration based on historical and literary records, a constant re-mantling intellectual activity is necessary.

${ }^{5}$ Walter Schmithals, on the English translation to Bultmann's commentary of the Fourth Gospel, asserts that Johannine writings share conceptualization, stylistic forms, dualistic characteristics and mythic patterns with gnostic expressions. Furthermore, in John's narrative there are anti-gnostic theological statements, even though there exist a similar language and terminology with gnostic circles (Schmithals, 1971, p. 9-10). Nevertheless, scholars must considerer that early Christian expressions are synchretic religious phenomena through which many Jewish and Hellenistic conceptualizations are amalgamated while sharing similar elements, languages and terms (Bultmann, 1969, p. 191-206). Indeed, as Raymond Brown states: "Johannine theological thought patterns have the influence of a combination of various ways of thinking during Jesus's own life time and after his death.” Consequently, this author suggests that these multiple layers must be taken into consideration as part of a milieu which is not restricted to later ecclesiological traditions but per-passed every discourse since the first compositions about Jesus and the Church (1966, p. Lxiv).
} 
“cannot be disproved” (Brown, 1966, p. LIII-LVI). ${ }^{6}$ Several studies on Pauline corpora reveal many elements in common with these ancient religious traditions as well. For now, a review about gnostic ideas and their possible presence within the particular textual traditions in specific correspondences accentuates our current theoretical dilemma and initiates a conversation about dismantling these confining theoretical categories. This is relevant for understanding biblical literary constructions and their respective receptions; since these also instigate an understanding about ancient religions at a crossroad of different perspectives in particular contexts and within cultural expressions, e.g., their textual elaboration. As a result, scholars cannot assure anything about direct gnostic relations within particular gospels or the Pauline corpus; but they can stress common elements shared by gnostic texts and New Testament writings. ${ }^{7}$

\footnotetext{
${ }^{6}$ Hans-Joseph Klauck shares this consideration, since mythic transmission of particular characters, some theological messages, stylistic patterns and cultural contexts provide enough elements for considering a common synchretic milieu in which later gnostic ideas would be established (Klauck, 2000, p. 433-436). Taking these hypothesis into account does not imply a necessary search for pre-Christian gnostic experiences or a attempt to relate primitive gnostic religious experiences with New Testament writings (Yamauchi, 1979, p. 140-141); nevertheless, this emphasizes the ambiguity in some early narratives as well as "a powerful mythic impulse" through which later receptions shape their ideas, expressions and theologies (Perkins, p. 74-76).

${ }^{7}$ In the particular case of Pauline epistles, this is based on key passages in the Pastoral letters that may be related to gnostic ideas and Pauline argumentations present in the Corinthian letters. The understanding of a later composition of Corinthians, in the same period of diverse Pauline traditions development corroborate these correspondence with later gnostic elements, specifically because of ecclesiological debates. The following literary elements in the Pauline corpus, specifically in the Corinthian letters, are sufficient to initiate a comparison between gnostic ideas and Pauline traditions: a. ascetic or Gnostic ideas as false doctrines in the Pastoral's letters (1 Tim 1:4; 2:11; 4:3; 5:13; 6:20-21; 2 Tim 2:17-18; Tit $1: 14)$; b. study of the term gnosis and its derivations and semantic parallels in Corinthians; c. ascetic detachment from the world (1 Cor 7:1); d. spiritualized eschatology (1 Cor 15:12) e. docetic Christology (1 Cor 2:8; 12:3); f. gnostic anthropological myth presence (1 Cor 2:6-8); g. dualistic reminiscence (2 Cor 2:46); h. the resurrection of the body (1 Cor 3b-15); i. notions about Spirit and flesh (Rom 7:24; 1 Cor 2:14-15; 15:44-46); j. possible antinomians and those who preach another spirit (2 Cor 11:4; 6:14-7:1); k. Paul's inferior gnosis (2 Cor 11:6) and
} 
There are multiple understandings and applications of the term Gnosticism in contemporary scholarship. ${ }^{8}$ Consequently, this term and its derivations carry evident issues of definition, including scholars who prefer to abolish this terminology altogether. This implies historical problems, specifically for those who seek support for discussing origins and genealogy. ${ }^{9}$ Dismantling a modern category seems to be one answer to the lack of material or textual evidence or in the abundant presence of data after Nag Hammadi discoveries. ${ }^{10}$ Michel Tardieu and Jean-Daniel Dubois provide a

weakness (2 Cor 10:10); l. arrogance because of achievements (2 Cor 10-12) contrasting with Paul's weakness (2 Cor 10:12); m. divine power and visions (2 Cor 5:13; 2 Cor 12:1-5) in contrast to a depiction of Paul as mundane (2 Cor 10:36; 12:1-10; 5:12-13) and inadequate (2 Cor 2:14-3:5; 4:1, 16).

${ }^{8}$ This diversity persists not only in the particular studies about religion in the ancient world, but also in the contemporary intellectual life. Giovanni Filoramo analyzes few considerations about gnosis and the modern world and concludes that there is a rediscovery of Gnosticism (Filoramo, 1992, p. xi-xix). Indeed, despite archeological discoveries, psychoanalytical and philosophical reflections are eminent considerations. Carl Gustav Jung and Martin Heidegger are two significant examples. The former suggests that a study of gnostic ideas in their historical foundations is "futile, for in that way they are reduced only to their less developed forestages but not understood in their right significance.” (Jung, 1977, p. 652). The latter is associated with gnostic ideas and influenced eminent scholars in the theme such as Rudolf Bultmann and Hans Jonas. Karen King not only summarizes modern ideas about the topic, but also mentions contemporary gnostic themes in religious, philosophical and literary circles (King, 2003, p. 1-15).

${ }^{9}$ Karen King suggests that this search for origins has an intention of defining Christian identity. Consequently, scholars must scrutinize their own assumptions, necessarily abandoning the term Gnosticism, partially or totally. Since a precise understanding of this term is not possible, those who employ it must qualify or categorize its usage. In addition, new methodologies should reject this "rhetoric of purity” based on researches of origins (King, 2003, p. 218-236).

${ }^{10}$ Michael Williams in his famous book, following Kurt Rudolph, affirms that the term "Gnosticism" has brought more confusion than clarification. Indeed, gnostic ideas are related to something inauthentic or, at least, not genuine (Williams, 1996, p. 263-264). This is also King's main thesis, since ancient herisologies influenced modern scholarship about the theme, directly and indirectly (King, 2003, p. 17-19, 218-236). Therefore, Williams argues that the diverse sources cannot be easily reduced to a "value reversal" or inverse exegesis and proposes new approaches or models, e.g., the notion of a Biblical Demiurgical as "typology for organizing several religious innovations and new religious movements” (King, 2003, p. 265266). King agrees that modern methodologies distort, oversimplify and cofound the ancient phenomenon, specifically because they associate truth with chronology, 
variety of pragmatic differences and distinguish between eight senses ${ }^{11}$ of the word gnostic: epistemological; ${ }^{12}$ employed by gnostic movements; ${ }^{13}$ heresiological; ${ }^{14}$ used by Clement of Alexandria; ${ }^{15}$

purity and uniformity. Thus, she also asserts that some assumptions must be abandoned (King, 2003, p. 228). Michel Desjardins addresses these modern projections over ancient religious phenomena. He suggests that scholars pay attention to particular texts and do inference based on concrete evidence. Nevertheless, he does not differentiate between some particularities and classifies Gnosticism as a subgroup under the Christian "umbrella." (Desjardins, 2005, p. 370-384).

${ }^{11}$ Many authors analyze the diversity of gnostic ideas in the history of western thought. Hans-Josef Klauck compares Clement of Alexandria and Ernst Bloch in order to expose similarities between ancient and contemporary thoughts (Klauck, 2000, p. 430-503). These parallels are fascinating since they signalize the importance of gnosis today and its everlasting ideas through innumerable receptions since the first centuries.

12 This epistemological sense is attested in Greek philosophy, especially in the platonic idea of pure or speculative knowledge which can be associated with contemplation (theoria). As Amelie Rorty asserts, theoria has a self-contained aspect that is not based on premises or unfolding stages, but rather, it is achieved in the act itself furnishing serenity (Rorty, 1978, p. 344-345). It is an activity of mind in relation to a proper object and finally, the source of every object in Plato and Aristotle. Those who are out of the cave are able to contemplate (R. 517); the human being who is able to contemplate (theoretical bios) is the most happy (eudamonia) for Aristotle's Ethics (EN X 7-9); the theoretical knowledge is about ousia, physis, aitia (causes) for their own sake (Metaph. I.2 982a29ff). Everything comes from Contemplation in Plotinus (Enn. III. 8).

${ }^{13}$ According to Tardieu and Dubois, this is a reception of platonic ideas within anti-legalistic movements that claim the existence of revelations while being related to pneumatic experiences (Tardieu and Dubois, 1986, p. 23-26). Nevertheless, this reception is not so simple to define and locate in the ancient world. Questions about positive and negative matter are good examples about these complex relationships between gnostic ideas and philosophical interlocutors (Corringan, 2000, p. 54-56; Pearson, 1984, p. 55-72). This diversity of perspectives and traditions is visible in the formation of groups in the literary codices, and also in the different contexts as these texts interact with philosophical schools and religious groups (Schenke, 1980, p. 608-616).

${ }^{14}$ This is usually depicted as orthodox ecclesiological tendencies trying to create boundaries and classifying authors and texts as Gnostics, which, according to Tardieu and Dubois, can be traced back to the biblical texts and in different movements (Tardieu and Dubois, 1986, p. 26-29).

${ }^{15}$ Clement (150-215) derives his usage from the Greek epistemological meaning. Therefore, he conceives a perfect idea through which would be possible to distinguish the false from the true. In addition, this gnosis allows a transformation based on the scriptures and traditions (Tardieu and Dubois, 1986, p. 29). Clement 
used by Evagrius Ponticus; ${ }^{16}$ the esoteric sense from the $16^{\text {th }}$ century; 17 the religious syncretistic approach; 18 and the psychological understanding. ${ }^{19}$

Consequently, the present overview does not aim to be a complete summary of all the possible meanings and uses of gnostic ideas, neither aims to have the right categorization about related ancient phenomena. The main purpose is to highlight some ideas present in particular texts in Christian biblical texts, e.g., the Gospels, the Pauline corpus, and the Pastoral letters, in order to open a

combines intellectual orientation and spiritual insights in order to create foundations and practical orientations (Jefford, 1993, p. 384. John Steely argues in his dissertation that "gnostic Christianity," according to Clement, "must be moral as well as intellectual," rejecting extreme asceticism and libertinism while being in harmony with the gospel traditions (Steely, 1954, p. 31). Andrew Pratt affirms that all the themes present in Clement's writings are in direct relation with the progress of gnosis, including the Eucharistic meal which carries spiritual and practical dimensions within tangible symbols of the body and blood of Christ (Pratt, 1987, p. 163-178).

${ }^{16}$ Evagrius Ponticus (345-399) was a student of Origen who accentuated the epistemological differentiation between praktike and gnostike. According to Ponticus, the contemplation of God is possible through apatheia, which requires a spiritual methodology to purify the soul (Tardieu and Dubois, 1986, p. 30).

${ }^{17}$ There were esoteric emergent traditions in Europe beginning at the Renaissance, which received the connotation of gnostic. In addition, the term was applied to documentary discoveries about magic and amulets in the ancient world (Tardieu and Dubois, 1986, p. 30-34). Bentley Layton attests that the term "Gnosticism" was used for the first time in 1669, in the middle of Catholic-Protestant polemics and is the fruit of an allegorical interpretation of the book of Revelation (Layton, 1995, p. 348-349).

${ }^{18}$ The syncretistic perspective appears with the study of comparative religions, which affirmed that gnostic movements were products of several syncretic eastern religious considerations. This means that gnostic ideas are not only from Hellenistic and Christian traditions. Debates about a pre-Christian gnostic presence or the emergent dissensions within Jewish and Christian communities remain, as discussed following.

${ }^{19}$ The psychological understanding of the term gnostic is based on a profound and universal human experience about alienation. Therefore, from a phenomenological point of view, not a materialistic approach, humans perceive a particular radical estrangement in the world (Tardieu and Dubois, 1986, p. 35-37). Jung's Red Book is an example of this perspective, since it provides innumerable parallels with ancient gnostic traditions and highlights human estrangements and innermost experiences (Jung, 2009). 
discussion about ecclesiological conflicts and their respective theological discourses initiated in late first century ${ }^{20}$. Gnosticism as an organized social movement with a coherent and uniform message is an unconvinced category; ${ }^{21}$ nevertheless, the existence of distinct elements that are simultaneously present in gnostic texts and New Testament writings is unquestionable. ${ }^{22}$

\footnotetext{
${ }^{20}$ This approach provides a critical evaluation of contemporary categories about Gnostic ideas and Gnosticism, which can be extended to other ancient religious movements. Furthermore, studying the formation of Pauline corpora, and their respective theological debates, furnishes scholars the opportunity to study the background of some Jewish-Christian elements later present in some Gnostics texts. Consequently, by using particular texts and their receptions throughout debates and conflicts, as well as merging diverse theological conceptualizations with their multiple social consequences, re-mantling our contemporary categories about ancient religion phenomena is mandatory. Indeed, as David Brakke proposes, there are multiform religious movements that, from a theoretical perspective, can be categorized under the term Gnosticism and its derivations. However, this is only possible if scholars consider the limitations of our academic models in face of the highly diverse, although finite, Early Christianities's framework. Therefore, the author argues in favor of a gnostic school of thought, with mythic expressions and ritual performances (Brakke, 2012, p. 29-111).This can hardly be denied when apologists and ancient authors are taken into account in the end of the second century. Nevertheless, taking into consideration these same elements through their literary mythic communication and possible liturgical actions in comparison with earlier authors and contexts, the same contemporary theoretical categories share common grounds with diverse religious phenomena, as will be highlighted following.

${ }^{21}$ A plurality of perspectives with social conflicts is present in any religious movement, specifically those in the ancient world. Nevertheless, "the social history of these various movements is notoriously obscure;” which, according to Williams, reduces our inferences to merely mental exercises in the absence of concrete data (Williams, 1996, p. 235-250). Therefore, Williams suggests that the term Gnosticism must be replaced, since it does not adequately describe ancient phenomena and carries prejudices and pejorative connotations (Williams, 1996, p. 263-266). King asserts that a "monolithic entity" that modern scholars call Gnosticism has never existed; she, then, summarizes significant scholarly positions concluding that subcategories of the term Gnosticism, limiting or eliminating its usage, do not yet provide an adequate systematization (King, 2003, p. 189, 216). Some methodological agreements exist between a minimalist and more optimistic approach: a search for common elements based on the texts themselves (Williams, 2005, p. 55-79; Pearson, 2005, p. 81-101). This may occur with refining the actual terminological terms (Pearson) or applying new categories (Williams).

${ }^{22}$ See footnotes 35-40.
} 
As a result, a brief scholarship review about some dimensions of Gnostic ideas in the ancient Mediterranean context provides historical and literary grounds to some textual analysis in the JewishChristian writings in order to highlight the possible presence of some elements that later would be associated with gnosis. There is a primeval milieu shared among particular communities based on several literary receptions in which different ancient religious phenomena, gradually, became consolidated. ${ }^{23}$ Therefore, after a concept clarification about Gnosis and Gnosticism, some exegetical and literary investigations problematize how this ancient idea and this modern theoretical term may assist understanding early Christian mythmaking and the reception of biblical authors in the ancient world. ${ }^{24}$

${ }^{23}$ Indeed, there are particular contexts to every single book, to every single tradition, to every single source. However, bearing in mind some main ideas on Redaction Criticism, Rhetoric Criticism, Reception Theory and the demand for seriously considering synchronic and diachronic methodologies in tandem, scholars wonder how Gnostic and other Apocrypha books are independent documents or share the same contexts as the canonical books (Evans, 2003a; Evans, 2003b, p. 430-456; Yamauchi, 2003, p. 29-55; Yamauchi, 1979, p. 129-141). This exceeds discussing prevalence or dates of composition, since elements for continuities and discontinuities from Jewish-Christian traditions are present in texts that would later become canonical and are also present in a significant number of other materials (Schröter, 2016, p. 24-46). The last redactions of the majority of New Testament books dialogue with tendencies that gradually would become part of distinct intellectual conceptions or different social movements. This does not imply that there would be a pre-Christian gnostic movement, nor that there are direct gnostic ideas on New Testament writings. Despite different interpretations on the essential characteristics present in diachronic and synchronic approaches, James Barr sustains that they cannot be isolated from each other, since "Nothing can be solved by canonizing one of these contrary approaches”. Furthermore, because of a lack of clear definitions on these terms, scholars who relate them to their original context in literary criticism are able to perceive many similarities based on portraying historical experiences in different ways (Barr, 1995, p. 1-14). The relationship between synchronic and diachronic approaches receives a significant impact when Narrative Criticism and Reception Theory provide discussions on how author and readers perform their respective tasks in the transmission of information, while shaping and being shaped by implied authors and readers (Beuken, 1995, p. 15-38; Hoftijzer, 1995, p. 98-114).

24 This is the main topic of the third part of these research where studies on specific biblical texts and their receptions in the first three centuries underscore diverse and 
The modern interest in Gnosticism emerges together with historical investigations about Christian origins which instigate respective apologetic consideration. Therefore, Karen King's main thesis attests that the search for origins and Christian apologetic perspectives are interconnected. This occurs throughout exegetical methodologies and hermeneutical speeches. ${ }^{25}$ Initially, scholars understood Gnosticism as a monolithic phenomenon, which was directly associated with philosophical reflection on religion, being characterized as a Hellenization of Christianity. ${ }^{26}$

This idea of an intra-Christian development shifted within some approaches in the History of Religions School. Instead of a gradual expansion from Greek philosophy, passing through Christian traditions into gnostic appearance, scholars suggest extra and preChristian roots for Gnosticism. ${ }^{27}$ Wilhelm Bousset affirms that Gnosticism is a combination of Platonism with oriental elements, showing dualistic-pessimistic tendencies, in opposition to Hellenistic ideals, gradually being incorporated into the "Great Church" or being developed in tandem (Bousset, 1970, p. 279-281). Richard Reitzenstein asserts common features between some ancient

significant concepts about the main Christian themes such as Jesus, the cosmos, power and so forth.

${ }^{25}$ King attests that new historical methodologies, which do not focus on chronological origins and transformations, favor contemporary speeches against diverse forms of colonialism and domination (King, 2003, p. 239-248).

${ }^{26}$ This statement integrates two different positions about Gnosticism. Ferdinand Baur asserts the idea about a philosophical reflection of religion based on the abundant use of allegory in the Hellenistic Jewish texts from Alexandria and gnostic materials. Consequently, this interpretation sustains a dualistic discourse through allegorical approaches to Jewish scriptures (Marjanen, 2005, p. 31-32). Conversely, Adolf Harnack suggests that Gnosticism is a later Christian development in direct contact with Hellenic culture. Thus, many of those who are contrary to early orthodoxy or "pre-Catholic" tendencies are associated with gnostic ideas (Harnack, 1901, p. 32-38). There are those who do not reject philosophy or speculation by following the apologetic fathers, even though extensive Hellenization was not tolerated, such as Origen's case (Harnack, 1901, p. 123-126).

27 "Gnosticism is first of all a pre-Christian movement which has its roots in itself. It is therefore to be understood in the first place in its own terms and not as an offshoot or a by-product of the Christian religion.” (Bousset, 1970, p. 245). 
religious practices and those that may be associated with Gnosticism, and he attempts to trace gnostic origins to Persian myths (Reitzenstein, 1921, p. 245-246). The main critique about these ideas relies on the lack of concrete evidence for inferences, which provides a very similar depiction to the patristic apologetic or, at least, within the same framework. ${ }^{28}$

Hans Jonas attempts to understand the ancient Zeitgeist while analyzing gnostic ideas through contemporary philosophical considerations, especially the phenomenological existentialism of Martin Heidegger. Consequently, he discusses how myths express objectivity through their symbolical constructions and mystical experiences (Jonas, 1993, p. 1-23, 203-223). Therefore, individuals find meaning for their existence in the transcendence (Jonas, 1993, p. 163-168), which can be obtained through gnosis. ${ }^{29}$ Gnosticism is composed as a result of the syncretism of diverse traditions with Jewish and Christian elements, including Hellenic, Babylonian, Egyptian, and Iranian. ${ }^{30}$ For these reasons, Jonas claims that gnostic ideas promote a revaluation of Hellenistic considerations based on cosmological, moral and anthropological notions. ${ }^{31}$ Additionally, Jonas attests that the abstract characteristics of his typology are based on the gnostic transcendental genesis within human conditions, found

\footnotetext{
${ }^{28}$ As Antti Marjanen summarizes, an anthropological myth in religious Persian texts does not exist, and chronological development constructions seem improbable in light of such diverse data (Marjanen, 2005, p. 38-45).

${ }^{29}$ Therefore, Hans Jonas argues: knowledge of God is something transcendent and unattainable through a revelatory experience with soteriological practical aspects (Jonas, 1972, p. 34-35). Several scholars criticize this generalization, denouncing its existentialist root and absence of historical and literary data (Waldstein, 2000, p. 340-372).

${ }^{30}$ Nevertheless, it does not mean that Gnosticism is merely a mosaic of different ancient perspectives (Jonas, 1972, p. 33).

${ }^{31} \mathrm{He}$ attests the following main elements: transcendence of deity; archons and materiality of the world; human needs gnosis to salvation; realized eschatology; pneumatics have sovereignty in the spiritual and practical realities (Jonas, 1972, p. 33). This leads him to compare ancient Gnosticism and existentialism as similar answers to the nihilistic problem in two different contexts. Hans Jonas is opening a philosophical dialogue within a Universal History purview, comparing these different eras throughout typologies based on prevalent human situations in his context.
} 
in power structures that require a soteriological speech (Jonas, 1970, p. 90-92). He concludes that a general systematization before textual diversity is impossible, since every text must be analyzed "case to case, and often more 'by ear,' musically as it were, than by abstract rule" (Jonas, 1970, p. 103). Finally, he asserts about the possibility of common features before the second century, nevertheless there is lack of a concrete "cosmic derogation" present in gnostic worldview. Consequently, Gnosticism is different, independent and with points of contacts with early Christian movements, providing answers to similar situations.

Kurt Rudolph assumes these mainstream considerations about the dualistic structure present in the gnostic movements while highlighting the variety of gnostic systems within their particularities. In addition, he asseverates the relationship between Christian and non-Christian elements together with Jewish and Platonic traditions while accentuating the theological judgments in the creation of boundaries (Rudolph, 1987, p. 51-52). Gnosis is a historical category to comprehend a particular worldview that involves dualism, cosmogony, soteriology, eschatology and cult, having immediate moral consequences (Rudolph, 1987, p. 57-59, 204-272). ${ }^{32}$ According to Rudolph, Gnosticism cannot be seen independently of Christian dogmatic development, since "the oldest theological systems were those of the Christian Gnostics." This does not mean that these two "worldviews" exclusively share the same origin, but they constantly interchange ideas (Rudolph, 1987, p. 369).

Jonas and Rudolph reflect, in different ways and generations, the resolutions attempted in the Messina conference, since they distinguish between gnosis and the different movements around this

32 This opens an interesting question about the organization of gnostic communities, since Rudolph attests the following: Gnosticism has no tradition on its own, being a parasite prospering in hosting religions (Rudolph, 1987, p. 55) and being a product of a syncretistic position in which change and conservation are together in a different context than the former religious traditions (Rudolph, 1987, p. 286-287). Consequently, scholars must decide if it is possible to understand Gnosticism as a particular religious movement or if it must be observed under diverse religious experiences in the ancient world. 
notion, including cultic and sociological aspects. ${ }^{33}$ Even though this conference did not generate an accepted consensus concerning these topics, it problematized modern concepts and categories to understand Gnosticism as an ancient phenomenon. ${ }^{34}$ The lower influence of Nag Hammadi, the idea of an elite group as a primary social location, the possibility of determining a sociological and cultic context and the discussion of the concept "Gnosticism" itself are posterior issues in the scholarship.

Social location deserves special attention to better understand the pragmatic consequences of gnostic ideas in their respective contexts. ${ }^{35}$ Carl B. Smith summarizes these positions in the three following characteristics (Smith, 2004, p. 244-249): Gnosticism rises among alienated Jewish intellectuals reflecting a diversity of Jewish elements such as mysticism, messianism, asceticism, apocalypticism

33 Studying the cultic and sociological context of the gnostic material is one recommendation in the final proposal at Messina. (Bianchi, 1970, p. xix). These characteristics are emphasized differently for both authors throughout their respective research; however, beyond the scope of this argument.

${ }^{34}$ Some of the main considerations follow: avoid undifferentiated use of gnosis and Gnosticism, since gnosis is related to "knowledge of divine mysteries reserve to an elite" while "Gnosticism is associate with certain group of systems in the second century"; Gnosticism can be systematized and summarized through myths of devolution and reintegration; gnosis requires divine consubstantiality and revelation; the existence of themes and motifs and a systematization before the second century are debatable; the question about previous conceptual developments (Weltgeschichte) is in order; a differentiation about the notion of dualism is necessary: anticosmic, Zoroastrian and metaphysical dualism (Bianchi, 1970, p. xxvi-xix).

${ }^{35}$ Hans Kippenberg proposes that Gnostic ideas subvert a rational dominant order without legitimating any political order, since they represent a powerless intellectual elite that is not acting for material transformation (Kippenberg, 1970, p. 229-231). He analyzes regular issues that occur when discussing social stratification from ancient texts, nevertheless he assures that human intellectual production interchanges with specific social locations, assuming that cultural expressions and ideological constructions are able to be observed through literary and historical critique (Kippenberg, 1970, p. 211-214). Nevertheless, there are those who claim a lack of primary evidence to sustain his arguments (Marjsnen, 2005, p. 47-49). Kurt Rudolph analyzes the economic structure of the Hellenistic orient, indicating Gnosis as a social protest through materialistic approaches to reality, assuming its urban characteristic and the spread of oriental cults (Rudolph, 1987, p. 289-94). 
and philosophical strains; ${ }^{36}$ Gnosticism rises from within Jewish Christianity, including those groups that wanted to gradually separate from Jewish traditions elevating Christ as savior; ${ }^{37}$ Hellenistic individuals who converted to Jewish-Christian communities with platonic ideas. None of these positions can separately explain gnostic phenomena as a whole while honoring textual diversity, even though "Jewish", "Christian" and platonic elements are essential to understanding these materials separately.

In conclusion, following the enthusiastic and triumphalist approaches that relate some New Testament writings with gnostic texts, there is a rejection of gnostic movements in the first century. ${ }^{38}$ Nevertheless, critical studies reveal a mandatory revaluation of modern scholarship categories, including essential terms such as Gnosticism and Gnosis. Therefore, those who aim to analyze gnostic elements in the ancient writings must carefully determine the context and define the terms in order to avoid ambiguity and misunderstandings. ${ }^{39}$ The

\footnotetext{
${ }^{36}$ Henry Green sustains that Gnostic and Christian traditions are "fusions" of Judaic and Helenistic ideas emerging in a socio-political context of distress and disorder. Therefore, he locates the origin of gnostic movements in sectarian groups in Egypt, which were oppressed by changes in the Ptolemaic models of production. He emphasizes mystical and not political elements that denote individualistic characteristics (Green, 1985, p. 261-265). Carl Smith also accentuates that Gnosticism rises in the context of Jewish social crisis; nevertheless, he prefers to associate this with the Jewish revolt under Trajan, specifically for considering the Bar Kokhba's revolt too late because of early gnostic teachings.

37 Taking into consideration social dissatisfaction, Robert Grant argues that the failure of apocalyptic-eschatological hope generates gnostic impetus, since realized eschatological thoughts furnish security and consolation. As a result, he sustains that Paul and the fourth evangelist gradually changed their positions evidenced by their resounding acceptance in later gnostic circles (Grant, 1966, p. 27-34).

${ }^{38}$ William Combs suggests that scholars must differentiate between "background" and sources; in other words, gnostic texts from the second century cannot be used as sources for NT teachings, but they do provide information for the ancient milieu (Combs, 1987, p. 195-212).

${ }^{39}$ Carl Smith states that the term "gnosis" applied in NT depends on definitions, and also relies on methodological assumptions about the data (Smith, 2004, p. 152155). Gerd Lüdermann asserts that gnostic mythic elements are present in the ancient worldview; therefore "there are many reflections of gnostic thought" in
} 
inexistence of gnostic textual references and religious organizations in the first century do not exclude the presence of shared ideas within the Christian Testament and other Jewish mythic configurations. ${ }^{40}$ This requires new frameworks and categories to evaluate the early Jewish-Christian movements' compositional processes, since categories of historical inquiry including Gnosticism, Apocalypticism, Ancient Magic and so forth are fictitious and elusive modern understandings. New approaches should be created in order to dismantle the artificial distinctions among such categories and open new spaces for integration. Consequently, it is possible to re-mantle these ancient religious horizons by taking into consideration the reception of the New Testament writings as well as the gathering of different textual traditions that gradually stipulate social boundaries, theological barriers and terminological bounds that did not exist during the primal composition periods.

earlier documents such as the Pauline letters and other New Testament traditions (Lüdermann, 2005, p. 121-132). No one summarizes better than Hans-Joseph Klauck: "While it is true that these far-reaching hypotheses have not withstood the test of a thorough examination, it is also true that one senses in the attitude of the Corinthians enthusiasts with whom Paul debates a number of traits that recall the later gnosis, and it remains at the very least worth asking whether Johannine writings in their final phase are involved in a defensive light against gnostic tendencies.” (Klauck, 2000, p. 436).

${ }^{40}$ Elaine Pagels asserts that this similar terminology can be better explained by the gnostic reception of Pauline letters (Pagels, 1992, p. 161-64). Elisabeth Fiorenza attests that the apocalyptic theological development in the book of Revelation may share polemics with enthusiastic gnostic tendencies in Asia Minor (Fiorenza, 1973, p. 565-581). Pheme Perkins asserts that New Testament writings do not directly mention gnostic texts; nevertheless, speculation remains about the composition, specifically because they share similar traditions and contexts. She concludes that "New Testament writers are not advocating gnostic ideas nor combating the formal systems that would emerge in the second century". According to Pheme Perkins, all the attempts to demonstrate that the Pauline adversaries had a Gnosticizing element failed, since systematic theological formalization did not exist in the first century. Nevertheless, local practices and exegetical traditions that would enrich later Pauline traditions and gnostic circles were already present (Perkins, 1993, p. 91-93). 


\section{Bibliography}

BARR, J. (1995). The Synchronic, the Diachronic and the Historical: A triangular relationship? In: JOHANNES, C. (ed.). Synchronic or Diachronic? A Debate on Method in Old Testament Exegesis. Leiden, Brill, 1995, p. 1-14.

BEUKEN, W. (1995). Isaiah 28: Is it Only Schismatics That Drink Heavily? Beyond the Synchronic Versus Diachronic Controversy. In: JOHANNES, C. (ed.). Synchronic or Diachronic? A Debate on Method in Old Testament Exegesis. Leiden, Brill, 1995, p. 15-38.

BIANCHI, U. (1970). Proposte. In: BIANCHI, U. (ed.). Le Origini dello Gnosticismo: Colloquio di Messina 13-18 Aprile 1966. Leiden, Brill, p. xix-xvi.

BOUSSET, W. (1970). Kyrios Christos: A History of the Believe in Christ from the Beginnings of Christianity to Irenaeus. Nashville, Abingdon Press.

BRAKKE, D. (2012). The Gnostics: Myth, Ritual, and Diversity in Early Christianity. Cambridge, Harvard University Press.

BROWN, R. (1966). The Gospel According to John I-XXII. A New Translation with Introduction and Commentary. Anchor Bible. New York, Doubleday.

BULtMANN, R. (1969). Le Christianisme Primitif: dans le Cadre des Religions Antiques. Paris, Petite Bibliothèque Payot.

COMBS, W. (1987). "Nag Hammadi, Gnosticism and New Testament Interpretation” Grace Theological Journal 8, n.2, p. 195212.

COOPER, J. (ed.) (1997). Plato. Complete Works. Edited with Introduction and notes. Indianapolis, Hackett Publishing Company.

CORRINGAN, K. (2000). Positive and Negative Matter in Later Platonism: The Uncovering of Plotinus's Dialogue with the Gnostic. In: TURNER, J.; MAJERICK, R. (eds.). Gnosticism and Later Platonism: Themes, Figures and Texts. Atlanta, SBL.

DESJARDINS, M. (2005). Rethinking the Study of Gnosticism. Religion and Theology 12, p. 370-384. 
EVANS, C. et alli. (2003a). Nag Hammadi texts and the Bible. Leiden, Brill.

EVANS, C. (2003b). The Interpretation of Scripture in the New Testament Apocrypha and Gnostic Writings. In: ALLAN, H.; WATSON, D. (eds.). History of Biblical Interpretation. Grand Rapids, William Eerdmans Publishing, p. 430-456.

FILORAMO, G. (1992) A History of Gnosticism. Cambridge, Blackwell.

FIORENZA, E. S. (1973). Apocalyptic and gnosis in the book of Revelation and Paul. Jornaul of Biblical Literature 92, p. 565-581.

GRANT, R. (1966). Gnosticism and Early Christianity. New York, Harper and Row.

GREEN, H. (1985). The Economic and Social Origins of Gnosticism. Atlanta, Scholar Press.

HARNACK, A. (1901). History of Dogma. Boston, Little Brown and Company.

HOFTIJZER, J. (1995). Holistic or Compositional Approach? Liguistic Remarks to The Problem. In: JOHANNES, C. (ed.). Synchronic or Diachronic? A Debate on Method in Old Testament Exegesis. Leiden, Brill, 1995, p. 98-114.

JEFFORD, C. (1993). Clement of Alexandria and Gnosis: a Dissertation in Review. Perspective in Religious Studies 20, n. 4, p. 381-396.

JONAS, H. (1970). Delimitation of the Gnostic Phenomenon: Typological and Historical. In: BIANCHI, U. (ed.). Le Origini dello Gnosticismo: Colloquio di Messina 13-18 Aprile 1966. Leiden, Brill 1970, p. 90-108.

JONAS, H. (1972). The Gnostic Religion: The Message of the Alien God and the Beginnings of Christianity. Boston, Beacon Press.

JONAS, H. (1993). Gnosis und Spätantiker Geist. In: RUDOLPH, K. (ed.). Von der Mythologie zur Mystischen Philosophie Erste und Zweite Hälfte. Göttingen, Vandenhoeck \& Ruprecht. 
JUNG, C. (1977). Foreword to Quispel: “Tragic Christianity”. In: READ, H. et al (eds.). The Symbolic Life: Miscellaneous Writings. London, Routledge and Kegan, p. 651-653.

JUNG, C. (2009). Red Book: A Reader's Edition. New York, Norton and Company.

KING, K. (2003) What is Gnosticism? Cambridge: Harvard University Press.

KIPPENBERG, H. (1970). Versuch einer Soziologischen Verortung des Antiken Gnostizismus. Numen 17, p. 211-231.

KLAUCK, H.-J. (2000). The religious Context of Early Christianity: a Guide to Graeco-Roman Religions. Edinburgh, T\&T Clark.

LAYTON, B. (1995). Prolegomena to the Study of Ancient Gnosticism. In: The Social World of the First Christians. Minneapolis, Fortress, p. 334-350.

LÜDERMANN, G. (2005). Did Gnosticism Ever Exist? In: MARJANEN, A. (ed.). Was There a Gnostic Religion? Göttingen, Vandenhoeck \& Ruprecht, p. 121-132.

MACKENNA, S. (1962). Plotinus. The Enneads. London, Faber and Faber.

MARJANEN, A. (2005). What is Gnosticism? From the Pastorals to Rudolph. In: MARJANEN, A (ed.). Was There a Gnostic Religion? Göttingen, Vandenhoeck \& Ruprecht, p. 1-53.

PAGELS, E. (1992). The Gnostic Paul: Gnostic Exegesis of the Pauline Letters. Philadelphia, Trinity Press International.

PEARSON, B. (1984). Gnosticism as Platonism: with Special Reference to Marsanes (NHC 10,1). The Harvard Theological Review 77, n. 1, p. 55-72.

PEARSON, B. (2001). Early Christianity and Gnosticism in the History of Religions. Studia Theologica 55, p. 81-106.

PEARSON, B. (2005). Gnosticism as a Religion. In: MARJANEN, A. (ed.). Was There a Gnostic Religion? Göttingen, Vandenhoeck \& Ruprecht, p. 81-101.

PERKINS, P. (1993). Gnosticism and the New Testament. Minneapolis, Augsburg Fortress. 
PERKINS, P. (1990). John's Gospel and Gnostic Christologies: The Nag Hammadi Evidence. Anglican Theological Review Supplementary Series 11, p. 68-76.

PRATT, A. (1987). Clement of Alexandria: Eucharist as Gnosis. Greek Orthodox Theological Review 32, p. 163-178.

RACKHAM, H. (ed.) (1934). Aristotle. Nicomachean Ethics. The Loeb Classical Library. Cambridge, Harvard University Press.

REITZENSTEIN, R. (1921). Das Iranische Erlösungsmysterium: Religionsgeschichtliche Untersuchungen. Bonn, Marcus \& Weber's Verlang.

RORTY, A. (1978). The Place of Contemplation in Aristotle's Nicomachean Ethics. Mind, New Series 87, p. 343-358.

RUDOLPH, K. (1987). Gnosis: The Nature and History of Gnosticism. New York, Harper \& Row.

SCHENKE, H.-M. (1980). The Phenomenon and Significance of Gnostic Sethianism. In: LAYTON, B. (ed.). The Rediscovery of Gnosticism: Procedings of the International Conference on Gnosticism at Yale New Haven, Connecticut, March 28-31, 1978. Leiden, Brill, 1980, p. 588-616.

SCHMITHALS, W. (1971). Introduction. In: BULTMANN, R. The Gospel of John: A Commentary. Philadelphia, The Westminster Press, p. 3-12

SCHMITHALS, W. (1965). Paul and James. London, SCM Press.

SCHMITHALS, W. (1971). Gnosticism in Corinth: an investigation of the letters to the Corinthians. New York, Abingdon Press.

SCHMITHALS, W. (1972). Paul and the Gnostics. New York, Abingdon.

SCHRÖTER, J. (2016). Apocryphal and Canonical Gospels within the Development of the New Testament Canon. Early Christianity 7, p. 24-46.

SMITH, C. (2004). No Longer Jews: The Search for Gnostic Origins. Massachusetts, Hendrickson Publishers. 
STEELY, J. (1954). Gnosis: The Doctrine of Christian Perfection in the Writing of Clement of Alexandria. PhD Dissertation. Southern Baptist Theological Seminary.

TARDIEU, M.; DUBOIS, J.-D. (1986) Introduction a la Littérature Gnostique. Paris, Cerf.

TREDENNICK, H. (ed.) (1935). Aristotle. Metaphysics. The Loeb Classical Library. Cambridge, Harvard University Press.

WALDSTEIN, M. (2000). Hans Jonas' Construct 'Gnosticism': Analysis and Critique. Journal of Early Christian Studies 8, p. 340372.

WILLIAMS, M. (1996). Rethinking “Gnosticism”: An Argument for Dismantling a Dubious Category. Princeton, Princeton University Press.

WILLIAMS, M. (2005). Was There a Gnostic Religion? Strategies for a Clear Analysis. In: MARJANEN, A. (ed.). Was There a Gnostic Religion? Göttingen, Vandenhoeck \& Ruprecht, p. 55-79.

YAMAUCHI, E. (1979). Pre-Christian Gnosticism in the Nag Hammadi Texts? Church History 48, p. 129-141.

YAMAUCHI, E. (2003). Pre-Christian Gnosticism: A survey of the Proposed Evidences. Eugene, Wipf and Stock Publishers.

Submitted in 01/11/2016 and accepted for publication 02/04/2017

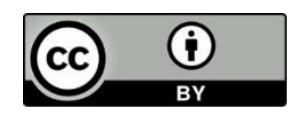

This is an Open Access article distributed under the terms of the Creative Commons Attribution License, which permits unrestricted use, distribution, and reproduction in any medium, provided the original work is properly cited. 